On Consciousness 
Other books by Ted Honderich published by Edinburgh University Press

After the Terror (2002; paperback 2003)

On Political Means and Social Ends (2003)

On Determinism and Freedom (forthcoming) 


\title{
On Consciousness
}

\author{
Ted Honderich
}

Edinburgh University Press 
(C) Ted Honderich, 2004

Edinburgh University Press Ltd

22 George Square, Edinburgh

Typeset in 11/13 Palatino and Futura by TechBooks India, and printed and bound in Great Britain by

The Cromwell Press, Trowbridge, Wilts

A CIP record for this book is available from the British Library

ISBN 0748618422 (hardback)

The right of Ted Honderich

to be identified as author of this work has been asserted in accordance with the Copyright, Designs and Patents Act 1988. 